SAKAI SAMBAYAN — Jurnal Pengabdian kepada Masyarakat

\title{
PENINGKATAN STATUS GIZI DAN KESEHATAN ANAK BALITA MELALUI PENINGKATAN PERILAKU SEHAT IBU DI BANGUNREJO LAMPUNG TENGAH
}

\author{
Khairun Nisa Berawi ${ }^{1}$, Dyah Wulan Sumekar ${ }^{1}$, Roro RWP, Putu Rystianing Ayu, Tiwuk \\ Susantiningsih ${ }^{1}$
}

Fakultas Kedokteran, Universitas Lampung, Bandar Lampung

Jl. Prof. Sumantri Brojonegoro No.1 Bandar Lampung 35145

Penulis Korespodensi : khairun.nisa@fk.unila.ac.id

\begin{abstract}
Abstrak
Berdasarkan survei yang dilakukan Kemenkes RI melalui riskesdas didapatkan prevalensi balita stunting di Indonesia meningkat dari 36,8\% (2007) menjadi 37,2\% tahun 2013. Kabupaten Lampung Tengah, Lampung didapatkan kejadian stunting paling tinggi yaitu 52,7\% berdasarkan Profil Kesehatan Provinsi Lampung tahun 2015. Penurunan prevalensi balita stunting menjadi salah satu prioritas pembangunan. Stunting terjadi akibat kurangnya asupan dan penyerapan nutrisi terutama pada 1000 hari pertama kehidupan dan merupakan masalah multifaktorial. Stunting memerlukan kerjasama lintas institusi termasuk managemen kesehatan keluarga yang membutuhkan peran ibu sebagai pengelola rumah tangga. Peningkatan perilaku sehat ibu diharapkan mampu meningkatkan status gizi dan kesehatan balita untuk mencegah stunting pada Balita. Kegiatan dilaksanakan melalui penyuluhan mengenai managemen balita sehat dan edukasi perilaku hidup bersih dan sehat pada ibu ibu PKK di Kecamatan Bangun Rejo, Lampung Tengah, yang diharapkan menjadi role model ibu sehat. Hasil pengabdian didapatkan peningkatan pengetahuan peserta berdasarkan hasil pre test diketahui 50, 55\% peserta mempunyai pengetahuan kurang dan 49,45\% peserta telah memiliki pengetahuan yang cukup dan hasil post test, diketahui bahwa $20 \%$ peserta cukup paham, 50\% telah memiliki pengetahuan yang baik dan $30 \%$ sangat baik. Diharapkan peningkatan pengetahuan dan edukasi yang diberikan akan membantu peningkatan perilaku sehat ibu sehingga mampu mencegah stunting pada balita.
\end{abstract}

Kata kunci: Balita stunting, managemen kesehatan keluarg, status gizi dan kesehatan balita

\section{Pendahuluan}

Salah satu masalah yang menjadi penghambat pembangunan adalah gizi buruk. Masalah gizi buruk serius yang banyak terjadi pada anak-anak adalah stunting. Pendek atau stunting didefinisikan sebagai ukuran tubuh seseorang dari stunting (pendek) <-2 SD hingga severely stunting (sangat pendek) <-3 SD (WHO,2014). Seorang anak dikatakan stunting apabila tinggi badan berbanding dengan usia (TB/U) berada dibawah nilai normal pertumbuhan anak.

Prevalensi balita stunting di Indonesia masih tergolong tinggi. Berdasarkan Riset Kesehatan Dasar (Riskesdas) tahun 2013, prevalensi balita stunting terus mengalami peningkatan dari tahun 2007 sebesar 36,8\%, 2010 sebesar 35,6\%, dan 2013 menjadi 37,2\% (Riskesdas, 2013). Hasil Pemantauan Status Gizi (PSG) tahun 2017, prevalensi stunting telah mengalami penurunan menjadi 29,6\% (Kemenkes RI, 2018), namun angka tersebut masih cukup tinggi, sehingga pemerintah memasukkan program penurunan prevalensi balita stunting sebagai salah satu prioritas pembangunan nasional periode 2015-2019 (Kemenkes RI, 2016). Lampung berada pada urutan ke-10 sebagai provinsi dengan kategori stunting sangat tinggi (>40\%) dan kabupaten Lampung Tengah adalah kabupaten dengan kejadian stunting paling tinggi di Provinsi Lampung yaitu 52,7\% (Kemenkes RI, 2018, Profil Kesehatan Provinsi Lampung, 2015, Dinas Kesehatan Lampung Tengah, 2018).

Kejadian stunting pada anak-anak jika dibiarkan akan berdampak pada individu maupun masyarakat, termasuk berkurangnya perkembangan kognitif dan fisik, berkurangnya kapasitas produktif dan kesehatan serta meningkatkan resiko terjadinya penyakit degeneratif seperti diabetes (UNICEF, 2013, Black RE et al, 2008, Briend A et al, 2015 ). 
Pendek atau stunting merupakan salah satu jenis gizi buruk (malnutrisi), penyebab utama masalah global penyakit pada masa pertumbuhan yang terjadi pada hampir $80 \%$ negara berkembang dan belum dapat terselesaikan. Efek lain dari gizi buruk seperti meningkatkan resiko penyakit, kerusakan tubuh yang irreversible, perkembangan otak yang tidak optimal sehingga mempengaruhi kemampuan kognitif bahkan sampai kematian pada anak (Mikhail WZA et al, 2013, widyakara nasional pangan dan gizi, 2004).

Stunting sering dimulai saat bayi masih berada di dalam kandungan dan berlanjut sampai usia 2 tahun pertama kehidupan karena bayi stunting setelah lahir akan terus mengalami penurunan Z-sore sampai sekitar usia 24 bulan. Apabila pada masa ini tidak dilalui secara benar maka akan menjadi jendela kritis untuk timbulnya proses aktif gizi buruk menjadi kerdil (stunting) (Black RE et al, 2008, Briend A et al, 2015).

Stunting berhubungan dengan asupan nutrisi yang rendah, kualitas makanan rendah dan infeksi berulang pada masa awal kehidupan anak atau sering dikenal 1000 hari pertama kehidupan (HPK). Infeksi berulang yang terus terjadi akan menjadi awal siklus berulang dari penyakit, gizi buruk dan imunitas yang rendah (WHO, 2018).

Penyebab stunting sangat sulit untuk diidentifikasi akibat sifatnya yang multifaktoral. Fakto-faktor yang sering menjadi penyebab diantaranya faktor orang tua, anak, rumah tangga dan masyarakat, sedangkan faktor yang secara tidak langsung berpengaruh adalah akses perawatan kesehatan, pendidikan, ekonomi, politik, dukungan sosial, urbanisasi dan kondisi kehidupan (Aridiyah FO 2015). Keadaan hygne yang buruk disertai infeksi saluran pencernaan berulang juga dapat menjadi faktor penyebab stunting (Black RE et al, 2008, Briend A et al, 2015).

Faktor tingkat orang tua termasuk status kerja ibu, pendidikan ibu, usia ibu, usia ibu saat melahirkan, status menyusui ibu, durasi menyusui, status perkawinan, pekerjaan pasangan, interval kelahiran, kunjungan antenatal dan cara persalinan. Faktor tingkat anak adalah jenis kelamin bayi dan infeksi saluran pernafasan akut (diartikan sebagai gejala batuk disertai dengan napas pendek dan cepat selama 2 minggu sebelum survey serta batuk dengan ledir ataupun lendir darah sebelumnya). Faktor tingkat rumah tangga adalah ketidak cukupan pangan dalam keluarga, indeks kekayaan keluarga serta sumber air minum. Terakhir adalah faktor masyarakat seperti jenis tempat tinggal, kelompok kasta, zona ekologi, zona geografis dan wilayah tempat tinggal ( Black RE et al, 2008, Briend A et al, 2015, Mikhail WZA et al, 2013).

Kondisi rumah tangga yang tidak mampu memenuhi kebutuhan pangan menyebabkan asupan nutrisi menjadi tidak adekuat. Nutrisi sangat penting untuk pertumbuhan dan perkembangan anak. Perkembangan anak tergantung pada faktor genetic, endokrin, sistem saraf otonom dan status gizi dan faktor fator ini juga turut memicu terjadinya stunting pada balita. Tiga faktor pertama memainkan peran penting terhadap perkembangan kognitif anak. Akibat terburuk yang menjadi masalah utama pada stunting adalah perkembangan otak yang tidak sempurna sehingga mengganggu fungsi kognitif. Anak-anak dengan fungsi kognitif yang tidak baik akan sulit menerima materi pelajaran di sekolah, sehingga hal ini akan membuat kemerosotan kualitas generasi pembangunan mendatang yang berperan dalam pembangunan suatu negara (Prendergast AJ and Jean HH, 2014).

1. Seorang ibu mendapat anugerah Tuhan untuk mengandung, melahirkan menyusui dan merawat anaknya, dengan fungsi reproduksi yang dimilikinya, yakni rahim untuk tempat tumbuh kembang janin dan payudara untuk menyusui anak pada masa pertumbuhannya. Peningkatan kualitas SDM dimulai sejak janin dalam kandungan, masa bayi, balita, anak-anak sampai dewasa. Pendidikan dan pengetahuan ibu tentang tumbuh kembang anak menjadi salah satu metode terbaik bagi peningkatan kualitas SDM sejak dini. Ibu juga menjadi inisitor inti dalam keluarga dalam mengoptimalkan kesehatan keluarga dalam kapasitasnya sebagai ibu yang berperan dalam mengatur pemeliharaan dan asupan gizi harian keluarga. Sehingga ibu memiliki peran penting dalam fase tumbuh kembang anak untuk membentuk tenaga pembangunan optimal dimasa yang akan datang. Tercapainya tumbuh kembang yang optimal akan menghasilkan sosok manusia yang sehat, cerdas, handal dan berkualitas prima untuk dapat melanjutkan pembangunan bangsa menuju masyarakat sejahtera adil dan makmur. Semua itu akan tercapai jika ilmu tumbuh kembang dimiliki dan diterapkan sejak dini dari keluarga terkecil terutama 
orangtua anak khususnya ibu. Sehingga untuk mengoptimalkan program pemerintah menurunkan angka kejadian stunting pada balita, edukasi yang akan diterapkan mengenai pengetahuan status gizi dan kesehatan dan perilaku sehat pada ibu ibu PKK Kecamatan Bangun Rejo, Lampung Tengah, mampu menjadi role model dalam dalam keluarga dan lingkungannya untuk meningkatkan status gisi dan kesehatan Balita di Kecamatan Bangun Rejo, Lampung Tengah khususnya.

\section{Bahan dan Metode}

Alat dan Bahan yang digunakan adalah: pamflet, poster, OHP, LCD, timbangan dan alat ukur tinggi badan, kuisioner.

Metode yang digunakan dalam pelaksanan program pengabdian masyarakat dengan mempersiapkan proposal dan anggaran biaya, rapat sosialisasi dengan tim, melaksanakan kunjungan pra survey ke lapangan untuk menentukan rencana kegiatan. Pengurusan ijin pelaksanaan kegiatan pengabdian kepada masyarakat di Dinas Kesehatan, Kecamatan dan Pengurus PKK Kecamatan Bangun Rejo, Lampung Tengah.

Hasil survey didapatkan Kabupaten Lampung Tengah memiliki angka prevalensi yang masih cukup tinggi berdasarkan hasil pemantauan status gizi (PSG) Balita kabupaten Lampung Tengah adalah kabupaten dengan kejadian stunting paling tinggi di Provinsi Lampung yaitu 52,7\% (Profil Kesehatan Provinsi Lampung, 2015).

\section{Hasil dan Pelaksanaan}

Kegiatan pengabdian Kepada masyarakat Fakultas Kedokteran Universitas Lampung khususnya bagi ibu-ibu PKK Kecamatan Bangun Rejo, Kabupaten Lampung Tengah dalam bentuk penyuluhan dan edukasi perilaku sehat, dilaksanakan pada bulan Oktober 2018. Para pengurus dan anggota ibu ibu PKK Kecamatan Bangun Rejo Kabupaten Lampung Tengah, diberikan materi penyuluhan mengenai managemen status gizi seimbang dan status gizi balita dan edukasi mengenai perilaku sehat ibu untuk mencegah balita stunting di lingkunganya khususnya Kecamatan Bangun Rejo, Kabupaten Lampung Tengah. Ibu ibu PKK diedukasi mengenai cara pengukuran status gizi balita dan bagaimana mengatur menu sehat bagi Balita.
Kegiatan ini dilaksanakan selama satu hari pada Kamis, 4 Oktober 2018 dari pukul 08.0014.00 WIB, bekerjasama dengan pengelola dan ibu ibu PKK Kecamatan Bangun Rejo sebagai penyedia tempat, pengelola dan ibu ibu PKK Kecamatan Bangun Rejo sebagai panitia, pengundang dan peserta pelatihan kegiatan. Sedangkan sarana, alat peraga, kuisioner dan materi penyuluhan dipersiapkan oleh tim pelaksana kegiatan.

Kegiatan ini bertempat di Kecamatan Bangun Rejo, Lampung tengah. Evaluasi yang dilakukan untuk menilai keberhasilan kegiatan ini terdiri dari evaluasi awal, evaluasi proses dan evaluasi akhir. Evaluasi awal dilakukan dengan memberikan pre-test kepada peserta yang berisi pertanyaan-pertanyaan yang terkait dengan materi yang akan diberikan. Berdasarkan data hasil pengamatan pretest, diketahui $50,55 \%$ peserta mempunyai pengetahuan kurang dan $49,45 \%$ peserta telah memiliki pengetahuan yang cukup. Hasil pre test yang rendah tersebut dikarenakan kurangnya pengetahuan dan pemahaman peserta tentang managemen status gizi dan kesehatan balita untuk mecegah Balita Stunting.. Materi yang diberikan mengenai Perilaku Hidup Bersih dan Sehat, Managemen Gizi dalam Keluarga, Managemen Tumbuh Kembang pada Balita, Managemen Asupan Gizi dan tahapannya pada fase tumbuh kembang Balita.
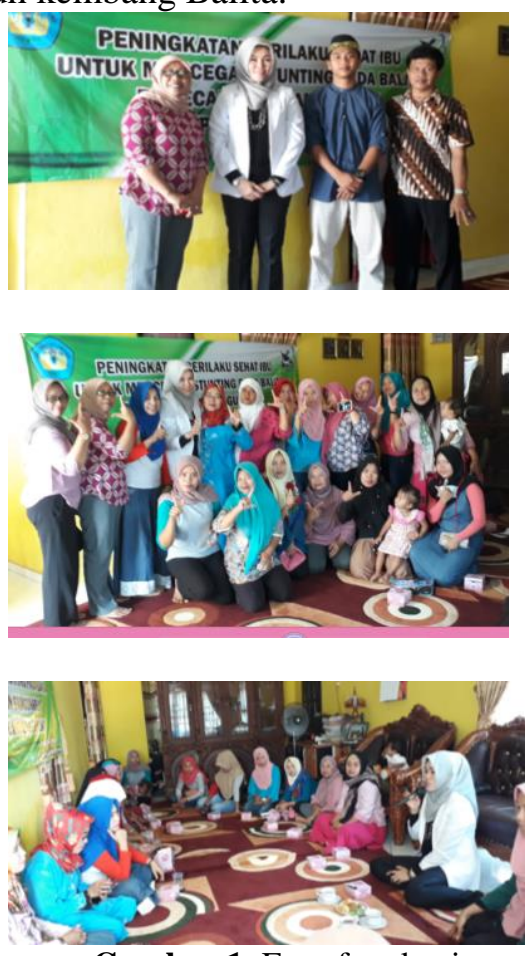

Gambar 1. Foto-foto kegiatan 
Berdasarkan data hasil pengamatan post test, diketahui bahwa $20 \%$ peserta cukup paham,50\% telah memiliki pengetahuan yang baik dan 30\% sangat baik.

\section{Kesimpulan}

Kegiatan pengabdian Kepada masyarakat Fakultas Kedokteran Universitas Lampung khususnya bagi ibu-ibu PKK Kecamatan Bangun Rejo, Kabupaten Lampung Tengah dalam bentuk penyuluhan dan edukasi perilaku sehat, dilaksanakan pada bulan Oktober 2018 mendapat respon yang baik dan membantu para ibu ibu PKK meningkatkan pengetahuan mengenai managemen status gizi dan kesehatan balita untuk mencegah balita stunting yang dibuktikan dengan peningkatan hasil evaluasi dari hasil pretest. Berdasarkan data hasil pengamatan pretest, diketahui $50,55 \%$ peserta mempunyai pengetahuan kurang dan 49,45\% peserta telah memiliki pengetahuan yang cukup. Berdasarkan data hasil pengamatan post test, diketahui bahwa $20 \%$ peserta cukup paham,50\% telah memiliki pengetahuan yang baik dan $30 \%$ sangat baik.

Diharapkan agar pelaksanaan pengabdian kepada msayarakat ini dapat membantu membentuk ibu ibu PKK Kecamatan Bangun Rejo Lampung Tengah untuk menjadi role model bagi lingkungannya dalam menerapkan perilaku sehat dalam keluarga dan masyarakat.

\section{Ucapan Terima Kasih}

Ucapan terima kasih terutama ditujukan kepada pemberi dana pengabdian kepada msayarakat yaitu pimpinan Lembaga Penelitian dan Pengabdian Kepada Masyarakat Universitas Lampung untuk pelaksanaan tahun 2018 dengan nomor kontrak DIPA BLU Nomor:2591/UN25/8/LPPM/2018. Ucapan terima kasih juga disampaikan kepada pihak-pihak yang membantu pelaksanaan penelitian, bapak camat Bangun Rejo, Eko Sumarsono, SE dan seluruh pengurus dan anggota PKK Kecamatan Bangun Rejo, Kabupaten Lampung Tengah

\section{Daftar Pustaka}

Aridiyah FO, Ninna R, dan Mury R. 2015. Faktor-faktor yang mempengaruhi kejadian stunting pada anak balita di wilayah pedesaan dan perkotaan. eJurnal Pustaka Kesehatan. 3(1): 163-170.

Badan Penelitian dan Pengembangan Kesehatan (Balitbangkes). 2013. Riset kesehatan dasar
(Riskesdas) 2013. Jakarta: Kementrian Kesehatan Republik Indonesia.

Black RE, Lindsay HA, Zulfiqar AB, Laura EC, Majid E, Colin M, dkk. 2008. Maternal and child undernutrition: global and regional exposures and health consequences.

Briend A, Tanya K, dan Carmel D. 2015. Wasting and stunting-similarities and differences: policy and programmatic implication. Food and Nutritional Bulletin. 36(1): S15-S23.

Dinas Kesehatan Lampung Tengah. 2018. Data 10 lokus desa stunting Kabupaten Lampung Tengah. Gunung Sugih: Dinas Kesehatan Lampung Tengah.

Dinas Kesehatan Provinsi Lampung. 2015. Profil kesehatan provinsi lampung tahun 2015. Bandar Lampung: Dinas Kesehatan Provinsi Lampung.

International Food Policy Research Institute (IFPRI). 2016. Global nutrition report 2016: from promise to impact: ending malnutrition by 2030 . Washington DC: IFPRI.

Kementrian Kesehatan Republik Indonesia. 2016. Situasi balita pendek. Jakarta: Pusat Data dan Informasi Kementrian Kesehatan Republik Indonesia.

Kementrian Kesehatan Republik Indonesia. 2018. Buku saku pemantauan status gizi tahun 2017. Jakarta: Direktorat Gizi Masyarakat.

Mikhail WZA, Hassan MS, Hanaa HE, Sahar AK, Hend YH, dan Maysa AS. 2013. Effect of nutrition status on growth pattern of stunted preschool children in Egypt. Acad J. Nutr. 2(1):1-9.

Prendergast AJ dan Jean HH. 2014. The stunting syndrome in developing countries. Paediatrics and International Child Health. 34(4): 250-265.

UNICEF, WHO, dan World Bank Group. 2018. Levels and trends in child malnutrition: key findings of the 2018 edition of the joint child malnutririon estimates. Geneva: World Health Organization.

Widyakarya Nasional Pangan dan Gizi. 2004. Ketahanan pangan dan gizi di era otonomi daerah dan globalisasi: program dan abstrak. Jakarta: LIPI.

World Health Organization. 2010. Nutrition landscape information system (NLIS) country profile indicators: interpretation guide. Geneva: World Health Organization.

World Health Organization. 2013. Childhood stunting: contex, causes, and consequences-WHO conceptual framework for stunting. Tersedia di: http://www.who.int/nutrition/events/2013_childh oodstunting_colloquium_14Oct_conceptualFram ework_colour.pdf.

World Health Organization. 2012. World health statistics 2012. Tersedia dari: http://www.who.int/gho/publication/world_helath _statistics/EN_WHS2012_Full.pdf. 
World Health Organization. 2018. Reducing stunting in children: equity consideration for achiefing the global nutrition targets 2025. Tersedia dari:

http://apps.who.int/iris/bitstream/10665/2602 02/1/9789241513647-eng.pdf. 